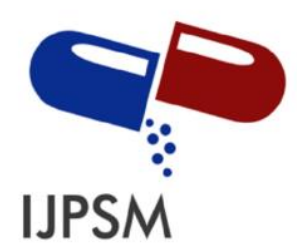

Zahara et al, Int. Journal of Pharmaceutical Sciences and Medicine (IJPSM), Vol.6 Issue. 5, May- 2021, pg. 40-44

\title{
Effect of Jatropha Sap (Jatropha curcas Linn.) on Incision Wound Healing in Female Mice (Mus musculus)
}

\author{
Zahara $^{1}$; Muhammad Mirza ${ }^{1}$; Rini Handayani ${ }^{1}$; Harrizul Rivai ${ }^{2 *}$ \\ ${ }^{1}$ STIKES Assyifa, Jl. Mr. Teuku Moh. Hasan No.110, Lamcot, Kecamatan Darul Imarah, Banda Aceh 23242, Indonesia \\ ${ }^{2}$ Faculty of Pharmacy, Andalas University, Limau Manih Campus, Padang 25163, Indonesia \\ "Email: harrizul@yahoo.co.id; harrizul@phar.unand.ac.id \\ DOI: 10.47760/ijpsm.2021.v06i05.005
}

\begin{abstract}
Jatropha as a medicinal plant has been very widely used. Among them can cure rheumatic joints, tetanus, epilepsy, and bronchitis in children. Jatropha sap can be used as an antimicrobial, relieves wound bleeding, treats digestive disorders, and treats mouth sores and toothaches. Many people still use traditional medicine to treat wounds. One that is used to treat wounds is jatropha sap. This study aims to determine the effect of the incision wound healing in mice (Mus Musculus) by giving Jatropha sap (Jatropha curcas, Linn) seen from the disappearance of inflammation dryness wounds and the tightening of the skin. This study uses a descriptive method through laboratory tests. Based on the study results, it is known that Jatropha sap has the effect of healing incise wounds in female mice, seen from the elimination of inflammation, drying of the wounds to the closure of the skin (granulation) compared to negative controls.
\end{abstract}

Keywords: Mus musculus, wound healing, Jatropha sap, Jatropha curcas Linn.

\section{Introduction}

Jatropha has long been known to the public in various regions of Indonesia, namely since the Japanese introduced it in 1942. At that time, the community was ordered to plant Jatropha as a yard fence. ${ }^{[1]}$ The benefits of Jatropha as a medicinal plant have been widely used. Jatropha root can cure rheumatic joints, tetanus, epilepsy, and bronchitis in children. At the same time, the seeds can treat difficulty defecating, cervical cancer, and so on. Jatropha leaves can also be used to cure itching, coughs, and hernias. Jatropha oil can be used to treat complex bowel movements, burns, and ulcers. While the jatropha sap can be used as an antimicrobial, relieves wound bleeding, treats indigestion, as well as treating mouth sores and toothache. ${ }^{[2]}$ Jatropha contains chemicals, such as triacontanol, alpha-amirin, cholesterol, beta-sitosterol, 7-keto-beta-sitosterol, stigmasterol, stigma-5-en-3-beta-7-alfadiol, vitexin, isovitexin, and cyanide acid. Jatropha leaves contain saponins, flavonoids, and polyphenol compounds, ether extract. The sap contains 11-18\% tannins, alkaloid compounds, such as Jatropha, jatrophone, and kursin. While the seeds contain various alkaloid compounds, saponins, and a type of toxic protein called kursin (the levels of toxins will decrease when heated), 35-45\% fatty oil consists of various triglycerides of palmitic, stearate, and workaholic acids. ${ }^{[3]} 7$-keto-beta-sitosterol, stigmasterol, stigma5-en-3-beta-7-alfadiol, vitexin, isovitexin, and cyanide acid. Jatropha leaves contain saponins, flavonoids, and polyphenol compounds, ether extract. The sap contains 11-18\% tannins, alkaloid compounds, such as Jatropha, jatrophone, and kursin. While the seeds contain various alkaloid compounds, saponins, and a type of toxic protein called kursin (the levels of toxins will decrease when heated), 35-45\% fatty oil consists of various triglycerides of palmitic, stearate, and workaholic acids. ${ }^{[4]}$ 7-keto-beta-sitosterol, stigmasterol, stigma-5-en-3beta-7-alfadiol, vitexin, isovitexin, and cyanide acid. Jatropha leaves contain saponins, flavonoids, and 


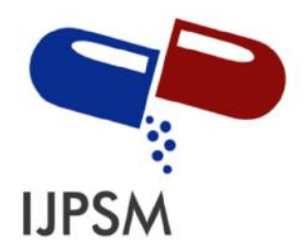

Zahara et al, Int. Journal of Pharmaceutical Sciences and Medicine (IJPSM), Vol.6 Issue. 5, May- 2021, pg. 40-44

polyphenol compounds, ether extract. The sap contains 11-18\% tannins, alkaloid compounds, such as Jatropha, jatrophone, and kursin. While the seeds contain various alkaloid compounds, saponins, and a type of toxic protein called kursin (the levels of toxins will decrease when heated), 35-45\% fatty oil consists of various triglycerides of palmitic, stearate, and workaholic acids. ${ }^{[5]}$

For first aid in wounds, povidone-iodine is usually used because it is straightforward to obtain, and the price is also relatively low. One that is often used to treat wounds in the village is to use jatropha sap. Almost all of the residents in the yard of the community plant a lot of Jatropha. It causes Jatropha curcas to be used more often by the public than povidone-iodine. Based on this, research will be conducted on the test of the effect of the incision wound healing in female mice by giving jatropha sap, is there an effect of healing incision wounds in mice by providing jatropha sap seen from the loss of inflammation,

\section{Materials and Methods}

\subsection{Research tools and materials}

The tools used in this study were scalpels, tweezers, scissors, blades, shavers, scales, magnifying glass, dropper pipettes, test tubes, red, black, and blue markers.

The materials used in this study were $70 \%$ alcohol, hand glove, cotton, jatropha sap, povidone-iodine with the trademark betadine, and cotton butt.

\subsection{Acclimatization of test animals}

Acclimatization of experimental animals before use, experimental animals, must be adapted to the environment. Acclimatization is carried out for a minimum of 14 days, during which time the experimental animals are only given and drinking until they reach the expected weight of $\pm 30 \mathrm{~g}^{[6]}$.

\subsection{The process of taking jatropha sap}

Picking the jatropha leaves by injuring the stalk of the jatropha plant, the Jatropha will produce a slightly whitish sap, then collect the jatropha sap with a test tube and take it to the laboratory.

\subsection{Treatment of mice}

Each test animal is weighed, each test animal is marked with a transverse line at the base of its tail with a colored marker (red for mice tested animals given castor sap, blue for mice given povidone-iodine (positive control), and black. For mice tested animals that were not given any treatment (negative control). In each mouse, the hair was shaved $3.0 \mathrm{~cm}$ in the area to be incised (hamstrings) then rubbed with $70 \%$ alcohol, then the mice were incised along with $\pm 1.0 \mathrm{~cm}$ depth reach the subcutaneous layer ${ }^{[5]}$. Animals were divided into three groups (each group consisting of three test animals). Test animals were given a black mark for group 1, then incised and given one drop of jatropha sap. A blue spot for group 2 mice was incised, then offered one drop of povidone-iodine solution, red mark group 3 was not given any treatment. Drug administration is carried out twice a day, namely in the morning and evening, until the wound has healed.

\subsection{Data analysis}

The data obtained will be presented in the form of a table, which shows the length of the healing period (days) through the process of observing the inflammation time (redness), the dry phase of the wound, and the phase of granulation formation (skin closure) and is analyzed descriptively. 


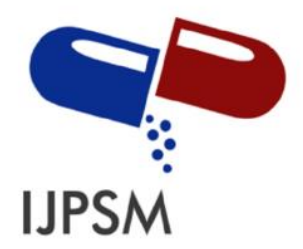

Zahara et al, Int. Journal of Pharmaceutical Sciences and Medicine (IJPSM), Vol.6 Issue. 5, May- 2021, pg. 40-44

ISSN: 2519-9889

Impact Factor: 3.426

\section{Results and Discussion}

In general, the tissue response to injury can be divided into three main overlapping stages, namely; Inflammation, granulation tissue formation (recapitalization, fibroplasia, wound contractions, angiogenesis), matrix formation, and remodeling ${ }^{[6]}$. In this study, the experimental stages in the healing phase of the incision wound in mice were the inflammation (redness) phase, the dryness of the wound, and the granulation formation phase (skin tightening). We observed the average time (days) required in the wound healing process after being dripped with Jatropha, povidone-iodine, and negative controls were observed from starting the process of eliminating inflammation as in Table 1.

Table 1: Observation Table of Time to Eliminate inflammation (redness)

\begin{tabular}{|c|c|c|c|c|c|c|c|c|}
\hline \multirow{2}{*}{ Treatment } & \multirow{2}{*}{$\begin{array}{l}\text { No. Test } \\
\text { Animals }\end{array}$} & \multicolumn{7}{|c|}{ Time for the disappearance of inflammation (redness) } \\
\hline & & Day 1 & Day 2 & Day 3 & Day 4 & Day 5 & Day 6 & Day 7 \\
\hline \multirow{3}{*}{$\begin{array}{c}\text { Jatropha } \\
\text { Sap }\end{array}$} & $\mathrm{I}$ & + & + & - & - & - & - & - \\
\hline & II & + & + & - & - & - & - & - \\
\hline & III & + & + & - & - & - & - & - \\
\hline \multirow{3}{*}{$\begin{array}{l}\text { Povidone } \\
\text { Iodine }\end{array}$} & $\mathrm{I}$ & + & + & - & - & - & - & - \\
\hline & II & + & + & - & - & - & - & - \\
\hline & III & + & + & - & - & - & - & - \\
\hline \multirow{3}{*}{$\begin{array}{c}\text { Control } \\
\text { Negative }\end{array}$} & $\mathrm{I}$ & + & + & + & - & - & - & - \\
\hline & II & + & + & + & - & - & - & - \\
\hline & III & + & + & + & - & - & - & - \\
\hline
\end{tabular}

Description: $+=$ Inflammation (redness)

$$
\text { - = Inflammation (redness) goes away }
$$

On the 1st and 2nd day after being incised of mice and dripping with povidone-iodine and control jatropha sap, there was an inflammatory phase with a reddish phase. It is consistent with what Sabiston 1995 stated that after the incision wound, local vasoconstriction would occur, which stops the bleeding. As soon as the injury occurs, acute inflammation develops, and the epithelium covers the wound. The scar tissue will form more slowly and remodel to tighten the wound's sides ${ }^{[7]}$. The inflammation disappeared on the 3rd and 4th days. For the wound that was dripped with povidone-iodine, the rash disappeared on the 4th and 5th day. The process observed next in the incision wound healing phase in mice was the dryness phase of the wound which can be seen in Table 2.

Table 2: Observation Table of Wound Drying Time

\begin{tabular}{|l|c|c|c|c|c|c|c|c|}
\hline \multirow{3}{*}{ Treatment } & \multirow{2}{*}{$\begin{array}{c}\text { No. Test } \\
\text { Animals }\end{array}$} & \multicolumn{9}{|c|}{ Drying Time of the Skin } \\
\cline { 2 - 10 } & Day 1 & Day 2 & Day 3 & Day 4 & Day 5 & Day 6 & Day 7 \\
\hline \multirow{3}{*}{ Jatropha Sap } & I & + & ++ & ++ & ++ & ++ & ++ & ++ \\
\cline { 2 - 10 } & II & + & ++ & ++ & ++ & ++ & ++ & ++ \\
\hline \multirow{3}{*}{$\begin{array}{l}\text { Povidone } \\
\text { Iodine }\end{array}$} & III & + & ++ & ++ & ++ & ++ & ++ & ++ \\
\cline { 2 - 10 } & I & - & + & + & ++ & ++ & ++ & ++ \\
\cline { 2 - 11 } & III & - & + & + & ++ & ++ & ++ & ++ \\
\hline
\end{tabular}




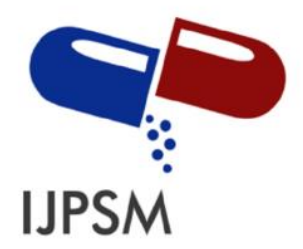

Zahara et al, Int. Journal of Pharmaceutical Sciences and Medicine (IJPSM), Vol.6 Issue. 5, May- 2021, pg. 40-44

ISSN: 2519-9889

Impact Factor: 3.426

\begin{tabular}{|c|c|c|c|c|c|c|c|c|}
\hline \multirow{3}{*}{$\begin{array}{c}\text { Control } \\
\text { Negative }\end{array}$} & I & - & - & + & + & ++ & ++ & ++ \\
\hline & II & - & - & + & + & ++ & ++ & ++ \\
\hline & III & - & - & + & + & ++ & ++ & ++ \\
\hline
\end{tabular}

The drying wound on giving jatropha sap after incising the wound starts on the 1st day, and the skin dries up entirely on the 2 nd and 3rd day. On the administration of povidone-iodine, the incision wounds began to dry out on the 2nd and 3rd day and completely dried up on the 4th and 5th day. In control, the wound drying was started on the 3rd and 4th days, completely drying on the 5th and 6th days. After the wound dries up, it turns into a scab and will peel off within one to two weeks, as stated. ${ }^{[8]}$. The final process observed from the incision wound healing process is the wound closure phase, as shown in Table 3.

Table 3: Table of Observation Time of Skin Gluing

\begin{tabular}{|c|c|c|c|c|c|c|c|c|}
\hline \multirow{2}{*}{ Treatment } & \multirow{2}{*}{$\begin{array}{c}\text { No. Test } \\
\text { Animals }\end{array}$} & \multicolumn{7}{|c|}{ Time to Close the Skin } \\
\cline { 2 - 9 } & Day 1 & Day 2 & Day 3 & Day 4 & Day 5 & Day 6 & Day 7 \\
\hline \multirow{3}{*}{$\begin{array}{c}\text { Jatropha } \\
\text { Sap }\end{array}$} & I & - & - & + & + & ++ & ++ & ++ \\
\cline { 2 - 9 } & II & - & - & + & + & ++ & ++ & ++ \\
\cline { 2 - 10 } & III & - & - & + & + & ++ & ++ & ++ \\
\hline \multirow{3}{*}{$\begin{array}{l}\text { Povidone } \\
\text { Iodine }\end{array}$} & I & - & + & + & ++ & ++ & ++ & ++ \\
\cline { 2 - 10 } & II & - & + & + & ++ & ++ & ++ & ++ \\
\hline \multirow{3}{*}{$\begin{array}{l}\text { Control } \\
\text { Negative }\end{array}$} & III & - & + & + & ++ & ++ & ++ & ++ \\
\cline { 2 - 9 } & II & - & - & + & + & ++ & ++ & ++ \\
\cline { 2 - 9 } & III & - & - & + & + & ++ & ++ & ++ \\
\hline
\end{tabular}

Description: - $=$ The skin is not yet closed

$+=$ The skin starts to close together

$++=$ Perfectly pressed skin

In the study, mice given Jatropha sap began to show their skin tightened on the 3rd and 4th day until the 5th to 7th day, and the skin was fully tightened. In mice, with the administration of povidone-iodine, the process of closing the skin looks faster, which has begun to look altogether closer. In mice that were without any treatment, the wounds were utterly close together. Wounds seemed close together on the 3rd day in the mice without any treatment and started to appear fully docked on the 5th day.

\section{Conclusion}

Based on the study results, it can be concluded that the jatropha sap affects the healing of incisions in female mice seen from the time the inflammation disappeared, the wound dried up. So the jatropha sap can be developed as a herbal remedy for incision wounds. 


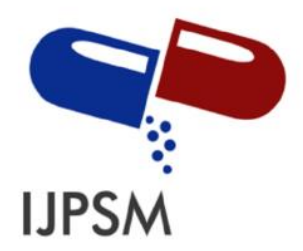

Zahara et al, Int. Journal of Pharmaceutical Sciences and Medicine (IJPSM), Vol.6 Issue. 5, May- 2021, pg. 40-44

ISSN: 2519-9889

Impact Factor: 3.426

\section{REFERENCES}

[1]. Hariyadi I. Jatropha cultivation, State Ministry for Research and Technology: Puspiptek Serpong. 2005.

[2]. Prihandana R, Hambali E, Mujdalipah S, Hendroko R. Profiting from jatropha. AgroMedia; 2007.

[3]. Erna S. Research and Development Center for Medicinal Plants. P3TO UNAS; 2009.

[4]. Malole MB, Pramono CS. Use of laboratory animals. Bogor Agricultural Institute: Jakarta. 1989.

[5]. Parry M, Busman H, Nurcahyani N, Sutyarso S. Potential of Ethanol Extract of Pare Leaves (Momordica charantia L.) as an Alternative Wound Healing Drug on the Back of Male Mice (Mus musculus L.). Journal of Applied Agricultural Research. 2017; 17 (2): 109-16.

[6]. Thakur R, Jain N, Pathak R, Sandhu SS. Practice in the study of plant wound healing. Evidence-based complementary and alternative medicine. 2011 Jan 1; 2011.

[7]. Sabiston DC. Surgery Textbook. EGC. Part 1. Medical Book Publishers: 1995.

[8]. Ibrahim R. Introduction to General Veterinary Surgery. Syiah Kuala Press University: Banda Aceh. 2000.

\section{A Brief Author Biography}

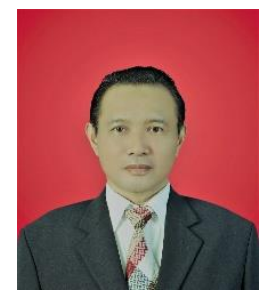

Prof. DR. Harrizul Rivai, M.S. was born in Payakumbuh, West Sumatra, on 4 September 1953. His father is Rivai Said, and his mother is Saridahanum Syofyan. The Author obtained a Bachelor of Pharmacy from the Department of Pharmacy, Faculty of Mathematics and Natural Sciences, Padjajaran University, Bandung (1976), a Master of Science degree from the Bandung Institute of Technology (1984), and a Doctorate from the Department of Chemistry, Faculty of Mathematics and Natural Sciences, Andalas University, Padang (2011). Now the Author is a Professor and Researcher at the Faculty of Pharmacy, Andalas University, Padang. The Author also serves as Deputy Chair of Academic Affairs at the YPTIK Padang College of Pharmacy (STIFARM). The Author wrote the book "Principles of Chemical Examination" (Publisher UI-Press, 1995), translated the book "Pharmaceutical Statistics" (EGC Medical Book Publishers, 2010), and wrote "Chapter 4" in the book "Recent Research Advances in Biology Vol. 4" (Book Publisher International, India, and United Kingdom, 2020), and wrote the book "Chinese Petai (Leucaena leucocephala): Traditional Uses, Phytochemicals, and Pharmacological Activities" (Deepublish, Yogyakarta, 2021). He wrote "Chapter 9" in the book "Recent Research Advances in Biology Vol. 7" and "Chapters 5, 6, 7, and 8" in the book "Technological Innovation in Pharmaceutical Research Vol. 3 (Book Publisher International, India, and United Kingdom, 2021). The Author has also written articles in various international journals in various science fields, such as chemistry, biology, and pharmacy. 